\title{
PUBLISHER CORRECTION OPEN Publisher Correction: Efficiently measuring a quantum device using machine learning
}

D. T. Lennon (iD, H. Moon, L. C. Camenzind, Liuqi Yu, D. M. Zumbühl, G. A. D. Briggs (D), M. A. Osborne, E. A. Laird (iD and N. Ares (iD npj Quantum Information (2019)5:96; https://doi.org/10.1038/s41534-019-0214-3

Correction to: npj Quantum Information https://doi.org/10.1038/ s41534-019-0193-4, published online 26 September 2019

The equal author contributions statement was not included in the final publication. This contributions statement has now been included:

These authors contributed equally: D. T. Lennon, H. Moon. (c) (i) Open Access This article is licensed under a Creative Commons cc) Attribution 4.0 International License, which permits use, sharing, adaptation, distribution and reproduction in any medium or format, as long as you give appropriate credit to the original author(s) and the source, provide a link to the Creative Commons license, and indicate if changes were made. The images or other third party material in this article are included in the article's Creative Commons license, unless indicated otherwise in a credit line to the material. If material is not included in the article's Creative Commons license and your intended use is not permitted by statutory regulation or exceeds the permitted use, you will need to obtain permission directly from the copyright holder. To view a copy of this license, visit http://creativecommons. org/licenses/by/4.0/.

() The Author(s) 2019 